\title{
Europe's engagement with China: shifting Chinese views of the EU and the EU-China relationship
}

\author{
Vincent K. L. Chang ${ }^{1} \cdot$ Frank N. Pieke $^{1}$
}

Received: 17 October 2017 / Accepted: 21 December 2017 /

Published online: 9 January 2018

(C) The Author(s) 2018. This article is an open access publication

\begin{abstract}
This article discusses the dramatic recent shifts in Chinese policy perspectives on the European Union (EU) and on EU-China relations. Whereas for more than a decade, policy makers and Europe specialists in China had regarded the EU as an exemplar of regional integration and as a promising new 'pole' in the global order, a recent survey shows that today, in the wake of the Eurozone crisis, the refugee crisis, and the 'Brexit' referendum, many perceive the EU as a troubled actor unfit to deal with the existential challenges confronting it, let alone play a credible leadership role beyond its own borders. Despite this, Beijing's ambitious international agenda at a time of increasing global uncertainty guarantees China's ever-growing stake in building a reliable, long-term partnership with the EU, even though recent Chinese diplomatic and economic initiatives are gravitating toward the Union's periphery, targeting subregional groupings of Member States along Europe's re-emerging, traditional fault lines. Based on the research findings presented in this paper, the authors argue that the EU and the Member States need to rethink the basic assumptions underlying their China policies in the so-called 'New Era' and explore new approaches of engagement that match these shifting perceptions, policies and political realities.
\end{abstract}

Keywords China-EU relations · Chinese perceptions · Chinese foreign policy · Subregional diplomacy

\section{Introduction}

Recent developments both in Europe, China and globally have made earlier studies on Chinese views of the European Union outdated, which is why the authors conducted a research of Chinese policy perspectives on EU-China relations that we report on in this

Vincent K. L. Chang

v.k.chang@hum.leidenuniv.nl

1 LeidenAsiaCentre, Leiden University, Matthias de Vrieshof 3, 2311 BZLeiden, the Netherlands 
article. Several English-language articles published over the past decade described Chinese views on Europe and China-EU cooperation. In 2006, Jing Men was one of the first to present Chinese perceptions of the European Union based on a review of leading Chinese journals. This was followed the next year by a study led by Martin Holland (2007) into public perceptions in several Asian countries - including Chinaof the EU. Around the same time, David Shambaugh, Eberhard Sandschneider and Zhou Hong (Shambaugh et al. 2008) edited a volume on China-EU relations including contributions on Chinese perceptions of the EU. Another volume on China and the EU edited by Dong Lichen, Wang Zheng Xu and Henk Dekker appeared in 2013 (Dong et al. 2013). In addition, several Chinese authors published articles in international journals in which they explained Chinese viewpoints and approaches concerning China-EU relations (e.g. Wang 2009, 2015; Song 2011; Chen 2012; Dong 2014).

The general picture emerging from these studies is one of consistently favourable and optimistic Chinese views of the EU and of EU-China cooperation, despite periodic setbacks and challenges. Several surveys portrayed the EU as an emerging global power and an example of regional political and economic integration (Zhu 2008; Song 2011: 238-9, Chen 2012: 13). Hitches in the European project, such as the failure of the European Constitution in 2005, were often dismissed as incidental setbacks with little effect on the EU's overall positive prospects (Chen 2012: 10). Even after the European debt crisis of 2011, many Chinese economists and Europe specialists expected the economic 'logic' of the EU soon to put the EU back on track (Zhang and Zhang 2011; interviews 1, 21; Zhang and Yu 2013; Dong 2014).

Several of these earlier studies benefited from generous funds made available by the EU for research in China (Dai 2008; Wang 2009). In contrast, since the Eurozone crisis, funding has dwindled and few new studies have been undertaken, causing some to speak of a 'marginalisation' of the discipline in China (interview 18). The few studies that have appeared recently offer theoretical approaches based on longer analytical timeframes (Zhang 2016) or study Europe's place in specific Chinese strategic narratives (Zeng 2017). Non-academic publications, including regular policy briefs and reports by the European Council on Foreign Relations, focus on specific themes or areas of cooperation, and likewise tend to lack comprehensive analyses of overall implications for EU-China relations.

\section{Project design}

For this article, we conducted semi-structured interviews with some 30 researchers in think-tanks, policymakers, diplomats, academics and professional observers in China and in Europe between the fall of 2016 and the summer of 2017. To promote participation and openness, our interviews took place under the condition of strict anonymity. The interviews were supplemented by extensive desk research of published sources in Chinese and English, including policy documents, official statements, news reports, media commentaries and academic publications.

This article builds on an earlier report on by the same authors (Chang and Pieke 2017). For this article, our analysis was expanded, reworked and updated with the aim of discussing key implications at the EU level. We have limited our research to Chinese perspectives. European perspectives on China's diplomacy and EU-China relations are 
already extensively covered in Western commentaries. These Western viewpoints are also well known to Chinese diplomats and observers and have essentially been accounted for in their policy views.

Large numbers of Chinese policy documents, official statements and speeches on foreign policy can be found, for example on the website of China's Foreign Ministry, along with reports from the daily press conferences it organises and statements from its spokespersons. Owing to their public nature, however, such expressions give only limited insight into the direction and scope of the policy debates and strategic aims underpinning these policies. These public sources need to be complemented by research on Chinese policy think tanks and research centres active in the field of foreign relations. Due to their dual role of advising the Chinese leadership on foreign policy and of developing, explaining and justifying Chinese policy to the outside world (Jacobson and Knox 2010: 34-36), Chinese researcher and advisers have an up-todate understanding of prevailing policy views, and in some cases, access to confidential information (Glaser 2013: 94). The fact that formally they are not part of the policy formation process allows them to offer key insights into how Chinese policymakers view the EU and the EU-China relationship.

Chinese official sources - written and oral - tend to downplay negative or confrontational perspectives, especially if there are no overriding tensions or rivalries at work. In the case of China and the EU, this 'positive' approach follows both from a general tendency to avoid open criticism in normal interaction, and from Beijing's desire to treat and endorse the EU as a major 'pole' in (its vision of) the yet imperfect multipolar global order (Zhu 2008; Wang 2009). There are, of course, varying degrees of the circumspection applied. In bilateral consultations, the Chinese do sometimes express stern criticism, but the content of these dialogues - or rather 'mutual monologues' according to some observers - is not made public (interviews 8, 9-10, 15).

\section{Finding 1: state of the union}

A first key finding of our research is that in the last 2 to 3 years, official Chinese perceptions of the EU have changed dramatically. In fact, our research suggests that a complete reversal of the optimistic attitudes mentioned before has taken place. This change came about in two stages. After the outbreak of the European debt crisis, from around 2011 onwards, the debate in China on the EU's future spit broadly into two camps. Often basing their views on downbeat American analyses, financial experts in China, and in their wake also more ideological Chinese political scientists, saw the crisis principally caused by structural problems within the EU which it was unable to address (Chen 2012: 13, interviews 1, 19, 21). Many Europe specialists and economists in China, however, brought up on the historical success story of the EU, continued to believe in the economic 'logic' of the EU, and remained cautiously optimistic about its future (interviews 1, 16, 21). Developments over the past 2 years have changed this. The refugee crisis, terrorist attacks and particularly the recent rise of nationalist sentiments in Europe, culminating in the Brexit vote in 2016, have revealed that truly profound problems are facing the EU (interviews 14, 17, 21). Virtually all Chinese participants in our research, including veteran EU specialists and previously optimistic economists, expressed strong doubts about the EU's capacity to root out these problems in the foreseeable future. 
Chinese commentaries list three essential problems that compromise the EU (interviews 21, 24; Chen 2012: 11-12). First, economic and political divisions between the Member States have deepened in recent years, partly due to the uneven impact of and recovery from the European debt crisis, and resulting in a reduced preparedness among Member States to look for common ground and accept political compromises. Second, the EU is found to be lacking the required institutional effectiveness and flexibility to implement the necessary reforms and reinvent itself. Third, the EU is plagued by a growing internal communications and legitimacy 'gap', as it has been increasingly incapable of reaching and convincing European citizens. Chinese observers expressed doubts as to the question whether the European Commission, which they perceive as conservative and federalist, will be able to bring the progressive and pragmatic political leadership required to overcome these structural internal problems (interviews $16,19,21,24)$. However, as a rational power taking a long-term view, Beijing, especially after the 'pro-European' outcome of recent elections in the Netherlands, France and Germany, also considers the possibility that a more constructive period may be dawning for the EU again (interview 30).

The increasingly inward-looking attitudes in several parts of the Western world contrast sharply with developing and emerging countries, including China itself, which in many ways are becoming more outward-looking, firmly embracing globalisation as a means of achieving progress. According to Chinese observers, this contrast fuels the perception in the developed West of a 'threat' from emerging countries like China, which is often seen as a 'winner of globalisation' - and therefore as a wrongdoer bearing primary responsibility for the adverse effects of globalisation. From a Chinese perspective, this is unfair and unproductive. Unfair because China too is paying the price for the uneven globalisation process, for example in the form of great social inequality and enormous environmental pollution in a country that for decades served as 'the world's workshop'. Unproductive because the solution does not lie in reversing globalisation. What is needed, from the Chinese point of view, is good regional institutions and sound socio-economic policy that can improve globalisation and mitigate its negative effects (Xi 2017a; Li 2017b). These are currently lacking, while the EU, with its decades of experience of integration and social value-traditions, should be able to lead this reform and bolster internal and external cooperation in this area (interviews 21, 24).

\section{Finding 2: compromised actor}

The Eurozone crisis revealed the structural problems of an economic union without a unified monetary policy. In the aftermath of the crisis, the (emerging) 'superpower' EU was gradually downgraded in the Chinese view to a regional trading block, even if still the world's largest. The post-Brexit 'loss' of the fifth-largest economy in the world further compromises the EU's economic punch. Politically, 'Brexit' would leave only France as permanent European delegate on the UN Security Council. More alarming is the effect of Brexit on other Member States who might be tempted to leave the EU as well (Song 2011: 240; interview 26). These uncertainties and concerns are being reinforced by the actions of US President Donald Trump, who has given public support to the fiercest critics of the EU, and raises doubts about the American security umbrella under NATO (interview 30). 
Because of all this, the EU's 'normative' or 'soft' power-its ability to promote and project its values, visions and ideals around the world - is fading. While China has always been sceptical about the EU's 'post-sovereign' normative mission with its imperative emphasis on Eurocentric values that it considers to be universal (Gerrits 2009; Wang 2009), now not only the moral justification is lacking from a Chinese point of view, but also the necessary political-economic backing (Chen 2012: 12-16; Chen 2016: 782). For all its values, ideals and talk of universality and humanity, so the analysis goes, the EU has been unable to build constructive relationships with its main neighbours, Turkey and Russia. It has failed to bring peace or stability in the Middle East and Northern Africa. It is unable to play a constructive role in sub-Saharan Africa. Moreover, it is even losing popular support in several parts of the 'Western' world, including its own national constituencies and the USA. As the decay in its support is not yet fully recognised in Europe, Chinese observers perceive a growing gap between capability and expectations in the EU's external behaviour (interviews 16, 24, 26).

The EU's normative power is further eroded by what Chinese observers see as its double standards (Wang 2009). European politicians for instance tend to treat terrorism and the refugee problem largely as external threats, while European commentaries typically present terrorist attacks in China by Tibetans or Uyghurs as the logical fallout of flawed policies (Liu and Dai 2016: 136). Not surprisingly, China is highly critical of Europe's support for humanitarian interventions aimed at regime change in Northern Africa and the Middle East. Their failure seems assured from the start, while their foreseeable consequences vary from highly adverse to disproportionately disruptive (Yan 2016; interviews 16, 21, 24). Chinese observers have a hard time accepting European criticism of China's human rights record (with its focus on individual violations) in view of the persistence of European policies that - in their view - help cause widespread and long-lasting violations of economic, social and political human rights around the world. The double standards applied by the EU in the field of human rights are thus construed as insincere and basically hostile toward China (interview 21; Pieke 2016: 84-86).

The Chinese government sees the realisation of human rights as a long-term, gradual process that cannot be delinked from the socio-economic development of a country. Beijing emphasises social and economic human rights. Moreover, in view of the importance of social and political stability, Chinese observers tend to acknowledge the view that civil rights also come with obligations, and that individual rights cannot simply be claimed to the detriment of this common interest (interviews 21, 29). Universal norms vary not only according to the level of economic development, but are also shaped by the social system and the cultural traditions and values of a country. Europe fails to accept this inevitable diversity and dynamism in the discourse on human rights, claiming the right to interpret universal rights according to its own, constantly evolving yet 'absolute' standards, and to interfere in the domestic affairs of other countries (Pieke 2016: 84-86; interviews 21, 29).

Against this background, China regards the bilateral human rights dialogue with the EU and with several EU Member States as a completely optional, non-binding form of friendly 'cultural' exchange (interviews 3, 5, 8, 16, 29). To the Chinese, public criticism outside of this dialogue does not befit the spirit of friendly and voluntary consultations. In case of such inappropriate criticism, China is thus well within its rights to delay or even cancel the dialogue, as has indeed happened in the case of some Member States 
(interview 8). However, concrete exchanges of expertise and experience regarding certain technical aspects of human rights - for example, reform of the courts system or prisons - are generally seen as constructive and welcome (interview 14).

\section{Finding 3: growing stakes}

Despite these critical views, our research suggests that the EU has not lost its strategic relevance to Chinese policymakers. On the contrary, the EU seems to regain some of its importance (interviews 1, 14, 16, 21, 26, 29). Geopolitically and strategically, this is a matter mainly of the relative relevance of the EU and the EU-China relationship to the Chinese view of the world. In this view, the unipolar world order dominated by the USA should make way for a multipolar one, in which global power is distributed among several major poles that jointly sustain the international order. Although the USChina relationship no doubt still is the central focus (Zeng 2017), the EU pole remains geopolitically important to Beijing. The EU is not only a counterweight to US hegemony and Washington's containment strategies, but also because China harbours a historically rooted distrust of its northerly neighbour Russia (Fu 2016: 2, 5; interviews $1,24)$, which will not simply disappear by mutual cheering of their 'best ever' bilateral relationship. Moreover, as China's expanding influence in Eurasia is likely to feed latent tensions with Russia, the EU's role as a balancing force is becoming increasingly important to Beijing (interviews 1, 24).

Rather than simply a pawn in a high-stakes power play, China views the EU as a long-term, principal partner, and a prosperous and stable Europe as conducive to peace and development. As inhabitants of the same landmass but not sharing direct borders, China and Europe share many common interests, while lacking the inherent tensions and rivalries of neighbours (Dai 2005; Zhu 2008; interviews 1, 6, 18, 21, 27). This also explains why the EU has not been marginalised in Chinese policy discussions as some recent studies have suggested (Zeng 2017). After the USA made its 'pivot' and later 'rebalance' to Asia in 2012, Chinese leaders paid a record number of visits to Europe, including a visit by President Xi Jinping to the EU headquarters in Brussels in 2014 and state visits to eight Member States. Beijing's proposal for a 'partnership for peace, growth, reform and progress of civilization' with the EU reveals its desire for a relationship of notably more depth and ambition than its 'strategic partnership' with Russia or its aspired 'major-power relationship' with the USA 'without conflict, without confrontation, based on mutual respect and win-win cooperation' (Xi 2014; interview 1). Furthermore, the envisaged revival of the old 'Silk Road' across the Eurasian continent underscores the principal place of Europe in Chinese long-term policy visions (Wang 2016: 65-70; interviews 6, 14, 16, 27).

In the face of today's 'global uncertainties' (Xinhua 2017), Beijing sees a growing convergence of views in several areas of common concern, including global trade and fighting climate change, as well as an urgent need to join opposing trade protectionism and isolationism. Chinese observers point out that, contrary to the USA, Beijing has consistently and publicly supported Europe's integration project, including during the darkest hours of the Eurozone crisis and Brexit (interview 1). With the prospect of a loss of the pro-free-trade British voice in the EU, China is looking at other Member States - including the Nordic countries and the Netherlands - to continue to push in 
Brussels for the promotion of free and inclusive global trade, and greater cooperation with China (interviews 14, 22, 29). Aside from Beijing's growing interest in the Arctic region, this was one of the reasons why Xi Jinping, en route to his first meeting with Trump in April 2017, made a stopover in Finland, a country known for its strong tradition of free trade (Tiessalo and Shi 2017). A few months earlier in January 2017, one the eve of Trump's 'America First' inaugural address, Xi took the spotlight in Davos to defend inclusive globalisation and free trade and boost cooperation with Europe. Less than half a year later, as Trump announced the US exit from the Paris Climate Agreement, Chinese premier Li Keqiang toured Berlin and Brussels seeking to renew and deepen commitment in the areas of climate, security and trade.

China is also looking to strengthen mutual ties in areas like security and trade in the bilateral (China-EU) sphere. Economically, the EU will remain essential for China as the largest global economy (even after Brexit), its most important trading partner and rapidly growing investment destination (Li 2017a; interviews 27, 30). Chinese readiness to cooperate with the EU therefore remains great, despite various recent setbacks in relations between the two sides (Chang and Pieke 2017: 30-31). Beijing strives in the shortest possible term for a feasibility study into a China-EU free trade pact and to be granted market economy status under WTO rules. China further hopes for speedy completion of the negotiations for a bilateral investment agreement. As Chinese investments in Europe are still in an early stage and - despite record growth in recent years - make up only a fraction of total incoming investments in the EU, an increase in these investments is therefore expected in the years ahead (Hanemann and Huotari 2016; Li 2017a). While Beijing likes to frame this in 'win-win' terms, Chinese observers nevertheless anticipate increasing bilateral tensions and hence acknowledge the importance of arrangements concerning market access, level playing field and dispute resolution (Li 2017a; interview 27).

In terms of importing advanced technologies from the EU, China finds that it is unduly restricted by the scope of the export bans under the EU arms embargo imposed in 1989 in the wake of the events at Tiananmen. The embargo is a thorn in Beijing's side primarily for political-symbolic reasons (Shi 2012), for China's own knowledge potential on defence issues has seen enormous increase in recent years. Objections to the export ban nevertheless still also have a practical element, as it limits the exchange of European technologies in such fields as new energy, new materials and environmentally friendly production (Li 2017a; interviews 27, 30).

\section{Finding 4: subregional differentiation}

Like other powers, China's approach to the EU has always been a dual one, its focus alternating between Brussels and individual Member States. Our research shows that the recent shift in Chinese perceptions of the EU coincides with the emergence of an increasingly differentiated, subregional focus, targeting clusters of individual Member States along Europe's traditional geographical division lines (Zhou 2013; Hu 2015; interviews 14, 16, 24, 27).

In Central and Eastern Europe (CEE), for example, China in 2012 launched the so-called ' $16+1$ ' platform as a practical mechanism to coordinate its bilateral contacts with $11 \mathrm{EU}$ Member States and 5 candidate Member States in the region to explore cooperation in 
infrastructure, industrial capacity and e-commerce (Long 2014; interviews 1, 14, 24). Besides a China-CEE think tank in Hungary, launched last year, the Chinese government initiated a China-CEE Investment Cooperation Fund in 2013, funded at an initial amount of 435 million US dollars for investing in CEE countries. During the summit in Riga in November 2016, the Industrial and Commercial Bank of China (ICBC) set up a US dollar 11 billion Sino-CEE Fund which aims to finance projects in Central and Eastern Europe.

Meanwhile, an informal dialogue is also taking shape with the Southern European countries. Their strategic maritime location and growing receptiveness for capital investments has led Beijing to consider the creation of a mechanism for cooperation modelled on the example of the ' $16+1$ ' China-CEE platform (Ekman 2016). The centre of China's strategic involvement in this region is the Chinesecontrolled Greek seaport of Piraeus, which features in Beijing's 'Belt \& Road' plans as a major hub connecting the maritime and overland routes (Van der Putten 2016). Further investments may be expected in the region in the years to come in areas such as port development, container capacity, cruise terminals, and tourism (Petrakis and Chang 2016).

In the Nordic region, China has been engaged for several years in semi-official dialogues at think-tank level on global trade, sustainability, innovation, arctic cooperation, and the development and security of the Northern Sea Route. Chinese policy makers and observers expect that this dialogue will be intensified in the years ahead in these areas, even more so now that ties with Norway have recently been normalised (Chang and Pieke 2017: 34, 38-39).

Western Europe is obviously important to Beijing as it represents the political and economic heart of the EU. In economic terms, it is attractive because of its high-tech industry and knowhow, its advanced financial centres, and its high-end consumer markets. Geostrategically, the region serves as a terminus of the 'Belt \& Road' plans, although it has no direct priority in the plans. To date, China has refrained from seeking an informal subregional dialogue in Western Europe, instead dealing with this region (and, incidentally, with the EU as a whole) primarily through the three key Member States - Germany, France and the UK - known in Chinese as the 'troika' (san jia mache). Only in these three Member States (and at the EU level) is Beijing represented by ambassadors of the top rank of vice-minister.

China's regional 'group' or 'forum' diplomacy, as it has been called (Hu 2015; Ekman 2016), is neither completely new, nor confined to Europe. In Africa, the Middle East and Latin America, China has developed similar mechanisms since 2000. Chinese observers characterise it as a mixed, informal type of collective political consultation, complementary to more formalised structures of bilateral and multilateral diplomacy (Hu 2015; interview 16). Although rooted in geostrategic considerations, Chinese observers do not think that the approach is driven by a geopolitical agenda in the traditional sense, but first and foremost by the need to facilitate China's growing country-to-region relations ( $\mathrm{Hu} 2015$; interview 24). In the context of China-CEE and China-Nordic exchanges, Chinese leaders have described subregional cooperation as a 'useful complement' to China-Europe relations and to the China-EU strategic partnership, one which could serve as a new 'growth driver' for China-EU cooperation and thus contribute to European prosperity (Long 2014: 57; Xi 2017b).

Despite the upbeat rhetoric, the Chinese leadership is aware of recurring concerns in Europe that China's subregional focus might be an attempt to play divide-and-rule and 
compromise the unity of the EU (Godement et al. 2011; Meunier 2014; Szczudlik 2016; interview 16). Chinese observers admit that Beijing is not averse to using its influence among Member States to its own advantage, thereby creating new fault lines or deepening existing ones within the EU (Shi 2012). However, they believe that China is neither to blame for these existing divisions, nor intent on structurally undermining or 'regrouping' the EU (Ding 2009: 32; Chen 2012: 12; Long 2014: 51, interview 16).

From Beijing's point of view, the political and socio-economic diversity of the EU is simply a reality that needs to be calmly faced and accepted as a departure point. It poses challenges, not only for the EU, but also for China, which suffers from the EU's complexity and would welcome greater internal coordination and unity among the Member States and institutions (Chen 2012; Shi 2012; interviews 14, 16, 21). But it also offers opportunities for cooperation between China and Europe, which ultimately will help overcome these differences and deepen European integration. In this context, Beijing also sees a role for Western Member States in its engagement for other parts of the Union. The idea is that Western European companies should team-up with China counterparts jointly to satisfy the demand for quality products in CEE countries ( $\mathrm{Li}$ 2016; interviews 14, 22).

\section{Reality checks}

Judging from public statements, it may seem as if recent events have had little impact on Chinese views of the EU and EU-China cooperation. As before, China publicly paints an optimistic picture of the EU and EU-China relations, voices support for European integration, and remains keen on deepening mutual ties. While the optics are indeed familiar, they conceal several major changes in their underlying dynamics. First, as our research has found, the EU's credibility as a regional and global actor has been deeply compromised from the Chinese point of view. Second, while the EU's influence and goodwill are waning, China is becoming more self-assured, assertive and influential on the international scene. President Xi Jinping also underlined this in his 3.5-h opening speech of the 19th CCP Party Congress (Xi 2017c). An important takeaway of this speech, confirming our chief findings, is that China today feels fully confident and fully determined to chart its own, unique development course by itself, without unsolicited advice, let alone external interference. In the 'New Era', heralded by Xi, China is asking to be accepted and respected for what it is and stands for, and that cooperation be built upon that basic premise. In his speech at the CPC in Dialogue with World Political Parties High-Level Meeting in Beijing on 1 December 2017, Xi went even further. He announced that the 'Concept of a community with a shared future for mankind' would be put into action, adding that the 'Belt \& Road' initiative is the practice of this concept (China Daily 2017). The explicit link with this China-centric initiative suggests clear Chinese special characteristics of the shared future for mankind.

It is important that the EU recognises and comes to grips with these shifting realities and accepts them as a basis for rethinking its China policy, which essentially is still premised on the idea of exerting normative power to 'mould China in its own image' (Fox and Godement 2009; Mattlin 2012). As things currently stand, the reality is that the EU simply lacks the power-'hard' and 'soft' - to command structural change in 
Chinese domestic policies, a fact reinforced by the unreliability of the USA as ally in terms of value-based policies. The EU and the Member States would therefore do well to rethink the viability and practicality of existing policies of projecting European 'core values' onto Chinese society, especially now that Beijing considers it one of its 'core interests' to keep out unsolicited advice or political interference. This is not to say that the EU should abandon its own values altogether in the face of shifting realities and growing global uncertainties. It does, however, suggest that the EU will need to adjust the scope and nature of its international values agenda.

In the absence of hard-power options, the only available means to the EU's ends are constructive ones. The inevitable conclusion that appears hard to accept for European politicians is that any such 'constructive' policy, to have any real effect in China, should be considered constructive by the Chinese leadership, unless of course the aim were to undermine Beijing's rule. Seen in this light, the much-criticised rejection by the Greek government in June 2017 of an EU statement criticising China's human rights record should not merely be dismissed as an irresponsible, illiberal act by a cash-strapped, renegade Member State (Emmott and Koutantou 2017). For Athens' view that 'unproductive and in many cases, selective criticism against specific countries does not facilitate the promotion of human rights in these states, nor the development of their relation with the EU', is not bereft of reason. Irrespective of the exact motivations of the Greek government, it raises the valid question whether public criticism will be conducive to structural improvements and reforms given the political system in China (interviews 14, 16, 21, 29).

This touches on a further reality highlighted by our findings. Despite mutually converging interest and reciprocal goodwill, the relationship with China reveals the EU's fundamental weakness as a global actor. The EU's inability to speak with one voice in its interactions with China is nothing new as such (Austermann 2012), but differences within the EU bloc have recently become increasingly visible and a frequent cause for embarrassment in its dealings with China. One example of this is the efforts of a number of Member States-including Greece, Hungary and Croatia - to pare down the joint EU statement on the verdict of the Permanent Court of Arbitration on the South China Sea conflict in 2016 (Emmott 2016).

It is, of course, easy to point at China's successful 'chequebook diplomacy' and 'wedge strategies' of splitting up the EU as the main cause of these rifts within the EU (Fallon 2016). Likewise, it is possible to blame Member States for undermining collective efforts to confront Beijing's disputed claims in the South China Sea or its crackdown on activists and dissidents (Cumming-Bruce and Sengupta 2017). But, as pointed out by others in the past, the root of these problems lies with the ineffective decision-making mechanisms and governance structure of the EU itself, and ultimately, with the structural economic, social and political differences that continue to exist between Member States.

A final reality that remains yet to be fully accepted across the EU is that there is no viable alternative for constructive engagement with China. Structural cooperation with China is imperative. In the absence of hard-power options the purported strategic dilemma of containment versus engagement is completely imaginary. Maintaining good relations with both China and the USA will allow the EU to retain influence and prevent it from being side-lined, whilst also 
providing it with leverage in its strained relationship with Russia. But this requires a firm and unambiguous acceptance of China as it is, including the Communist Party that leads it. To see the CCP not as a credible partner, but as an obstacle to or object of desired change, is to chart a course toward conflict and confrontation.

\section{Constructive engagement}

Europe will have to prepare itself for increased levels of Chinese investments and economic activity in the EU and its neighbourhood-after Africa, Oceania and Latin America, China's 'great leap outward' is now also directed toward Europe (LeCorre and Sepulchre 2016: 149). Instead of Europe engaging China', Europe will therefore have to concern itself increasingly with how to respond to China's engagement of Europe.

The Chinese 'Belt \& Road' initiative may be wide-ranging, unfocussed and grandly ambitious, but is not, at its core, threatening to Europe. Despite the enormous challenges will entail for the EU, the initiative also offers real opportunities to enhance Europe's economic growth and internal integration. Europe should embrace those aspects that are aimed at open-ended, inclusive cooperation, both as a way of engagement and cooperative growth, and as a means to co-shape, modify or at least monitor China's rise and its impact on Europe. Having said that, China's global initiatives such as the Belt \& Road plan are increasingly shaped by a coordinated strategy of the leadership in Beijing to increase China's role in world affairs both economically, culturally, diplomatically and strategically. Europe should be aware that in this strategy, the continent is to China as much a playing field as a strategic partner. Critical assessments of the implications of China's bold initiatives are therefore more than ever needed, but to be effective, should go together with a positive engagement with the fundamentals of such initiatives.

The Beijing-led Asian Infrastructure Investment Bank (AIIB disproved many prior concerns and fears in the West, in part because of the active involvement of several EU countries as founding members. Although the uncoordinated accession by 14 EU Member States again demonstrated the EU's lack of internal solidarity, these founding members made significant contributions during the critical initial stages of the bank by successfully promoting and developing standards for transparency and environmental and social policies (Xinhua 2016; Harada 2017). Building on this successful precedent, the EU could take an active stake in the development of the 'Belt \& Road' initiative. The EU could explore pathways of ensuring sustainable implementation across the EU of concrete projects that do justice to European values, needs and interests thus enhancing EU ownership of the initiative. An active dialogue with China is needed, which could, for example, be initiated in a semi-formal setting by European and Chinese think-tanks.

There are of course many difficult hurdles to overcome. When China argues in favour of global free trade and inclusive globalisation, it is primarily concerned about ensuring foreign consumer markets for its own exports, relieving excess capacity in domestic industries, and securing access to resources, commodities 
and investment opportunities. The EU on its part is primarily concerned with reciprocity and a level playing field for European investments in China (EC and HR 2016: 8-9), seeking greater access to several key sectors of the Chinese, economy, including the automotive industry, financial services and utilities (EU Chamber 2016; Wu 2017).

As a central tenet of international relations, reciprocity is not so much about creating equal conditions at any given point in time, as it is about making an equal effort and concessions along the way. Instead of debating matters of principle, the EU and China should therefore focus on securing concrete, practical deals on a quid-pro-quo basis, for example in the sphere of agreeing export quota on Chinese steel in exchange for granting it market economy status. While such a 'bartering' approach undoubtedly has its limitations, it is only by taking practical steps that it will be possible to move 'strategic' cooperation beyond rhetoric and to make real progress. Internally and strategically, the EU should not be fixated on full and immediate reciprocity, but should make sure that proper mechanisms are in place for effectively assessing the risks of inbound Chinese investments. The EU faces the task of renegotiating an practical understanding of free trade and globalisation that takes into account both Xi Jinping's understanding of 'win-win' and Donald Trump's take on 'fair trade' and 'America first', and which also does justice to the economic differences and diverse needs of the Member States.

\section{Conclusion}

Our research underscores the persistent paradox plaguing EU-China relations. Both sides have no choice but to cooperate in the light of their deep interconnectedness, their shared interests and contemporary geopolitical realities. Yet, at the same time, fundamental and persistent differences of principle, policy and practice remain. Moreover, cooperation with China lays bare the internal divisions and fundamental vulnerability of the EU. Partnership with China therefore is a litmus test for the EU and a measure of the internal unity and external effectiveness of the EU. Choices for more, less or a differentiated multi-speed Europe may cater to the real differences between Member States, but at the same time run the risk of deepening existing fault lines across Europe. They may respond tactically to the subregional focus of China's diplomatic initiatives, but may also simultaneously further compromise the EU's external leverage. In the final analysis, the China policy of the EU as a whole and of individual Member States is not principally about China. Its starting point does not lie in China, but in confronting challenges at home. In other words, the EU's policy towards China is first and foremost a matter of choices about the future of European cooperation and union.

The findings of our research may serve as an urgent reminder that the EU will have to continuously prove its own raison d'etre and show global actors like China, through deeds rather than words, that relations with the $\mathrm{EU}$ as such will remain more efficient than relations with the individual Member States. Internally, Brussels and the Member States will have to convince European constituencies that their national governments will be far better equipped to deal with and benefit from China's rise within the context of the EU context rather than individually. 
A sound approach is needed for effective engagement with China. Politically, Europe will have to accept Chinese foreign policy initiatives as welcome ways of engagement; diplomatically and technically, it should stand firm on European standards and values and negotiate adequate safeguards; strategically, it should prioritise policy objectives and develop mechanisms to deal with related risks, while psychologically, Europe will have to prepare for a further shift of realities in which Chinese perceptions will be increasingly relevant. Continuous research of China in Europe is vital, and should be complemented by support for European studies in China. Increased bilateral dialogue at the think-tank level could make key contributions to bridging existing divides, and help lessen the information gap that still characterises public debate on China in Europe.

Chinese perceptions cannot dictate how Europe engages with China. Yet, there can be no doubt that the changing facts on the ground urgently call for a reality check in Europe, and a shift from engaging China based on preconceived notions to mutual engagement on terms that serve Europe's interests. Fresh thinking is needed on how to respond to Chinese initiatives in responsible and, above all, more realistic ways.

Open Access This article is distributed under the terms of the Creative Commons Attribution 4.0 International License (http://creativecommons.org/licenses/by/4.0/), which permits unrestricted use, distribution, and reproduction in any medium, provided you give appropriate credit to the original author(s) and the source, provide a link to the Creative Commons license, and indicate if changes were made.

\section{References}

Chang VKL, Pieke FN (2017) China, the EU and the Netherlands: a Chinese perspective. LeidenAsiaCentre, June. http://www.leidenasiacentre.nl/en/china-de-eu-en-nederland-een-chinees-perspectief. Accessed Oct 2017.

Chen ZM (2012) Europe as a global player: a view from China. Perspectives 20(2):7-29

Chen ZM (2016) China, the European Union and the fragile world order. J Common Mark Stud 54(4):775792

China Daily (2017) Highlights of Xi's speech at world political party dialogue. China Daily, 1 December. Retrieved 22 December 2017, from http://www.chinadaily.com.cn/china/2017-12/01/content_35161658. htm

Cumming-Bruce N, Sengupta S (2017) In Greece, China finds an ally against human rights criticism New York Times, 19 June. Retrieved 5 July 2017, from https://www.nytimes.com/2017/06/19 /world/europe/china-human-rights-greece-united-nations.html

Dai BR (2005) Zouxiang chengshu jiankang wending de zhongou guanxi. Ouzhou Yanjiu 23(2):73-82

Dai BR (2008) European studies in China. In: Shambaugh D, Sandschneider E, Zhou H (eds) China-Europe relations: perceptions, policies and prospects. Routledge, London and New York, pp 105-126

Ding YH (2009) Jingshouzhu shijian kaoyan de Zhong-Ou guanxi. Ouzhou Yanjiu 5:29-33

Dong LS (2014) Chinese perceptions of the European Union. J Contemp China 23(88):756-779. https://doi. org/10.1080/10670564.2013.861172

Dong LS, Wang ZX, Dekker H (eds) (2013) China and the European union. Routledge, London and New York

Ekman A (2016) La Chine en Méditerranée: un nouvel activisme. Pol Étrangère 81(4):73-84

Emmott R (2016) EU's statement on South China Sea reflects divisions. Reuters, 15 July. Retrieved 5 July 2017, from http:/www.reuters.com/article/southchinasea-ruling-eu-idUSL8N1A130Y

Emmott R, Koutantou A (2017) Greece blocks EU statement on China human rights at U.N. Retrieved 5 July 2017, from http:/www.reuters.com/article/us-eu-un-rights-idUSKBN1990FP 
European Chamber of Commerce in China (2016) European business in China: position paper 2016/2017. Retrieved 5 June 2017, from http://www.europeanchamber.com.cn/en/publications-position-paper

European Commission (EC) and High Representative (HR) of the Union for Foreign Affairs and Security Policy (2016) Elements for a new EU strategy on China. Retrieved 5 June 2017, from http://eeas.europa. eu/archives/docs/china/docs/joint_communication_to_the_european_parliament_and_the_council_elements_for_a_new_eu_strategy_on_china.pdf

Fallon T (2016) The EU, the South China Sea, and China's successful wedge strategy. Asia maritime transparency initiative. Retrieved 5 June 2017, from https:/amti.csis.org/eu-south-china-sea-chinassuccessful-wedge-strategy

Fox J, Godement F (2009) A power audit of EU-China relations. European. Council on Foreign Relations, London

Fu Y (2016) Zhong-E guanxi: shi mengyou haishi huoban? Xiandai Guoji Guanxi 4:1-10

Gerrits A (2009) Normative power Europe: introductory observations on a controversial notion. In: Gerrits A (ed) Normative power Europe in a changing world: a discussion. Netherlands Institute of International Relations Clingendael, The Hague, pp 1-8

Glaser BS (2013) Chinese foreign policy research institutes and the practice of influence. In: Rozman G (ed) China's foreign policy: who makes it, and how is it made? Palgrave Macmillan, New York, pp 87-124

Godement F, Parello-Plesner J, Richard A (2011) The scramble for Europe. European. Council on Foreign Relations, London

Hanemann T, Huotari M (2016) A new record year for Chinese outbound investment in Europe. Mercator Institute for China Studies, Berlin

Harada I (2017) China-led lender draws members, not staffers. Nikkei Asian Review, 17 January. Retrieved 17 January 2017, from http://asia.nikkei.com/Politics-Economy/International-Relations/China-led-lenderdraws-members-not-staffers?page $=1$

Holland M (ed) (2007) The EU through the eyes of Asia: media, public and elite perceptions in China, Japan, Korea, Singapore and Thailand. WWZ, Singapore and Warsaw

Hu DW (2015) Analysis of the group cooperation diplomacy of China, with discussion of China-CEEC Cooperation. China. Int Stud 6:40-57

Jacobson L, Knox D (2010) New foreign policy actors in China. Stockholm International Peace Research Institute, Stockholm

LeCorre P, Sepulchre A (2016) China's offensive in Europe. The Brookings Institution, Washington D.C.

Li KQ (2016) Keynote speech at sixth Economic and Trade Forum of China and Central and Eastern European countries, 6 November. Retrieved 5 July 2017, from http://www.fmprc.gov.cn/mfa eng/topics_665678/lkqfwjejssthskstltwyelsbcxxlgjhy/t1413721.shtml

Li G (2017a) Economic ties stabilize China-EU relations. China Today, 5 January. Retrieved 20 February 2017, from http://www.chinatoday.com.cn/english/report/2017-01/05/content_733386.htm

Li KQ (2017b) Address at opening ceremony of annual meeting of 'New Champions 2017', 27 June. Retrieved 5 July 2017, from http://www.fmprc.gov.cn/mfa_eng/Zxxx_662805/t1474460.shtml

Liu M, Dai YC (2016) Non-conventional security cooperation: a rising priority for deepening the China-EU comprehensive strategic partnership. In: Islam S (ed) EU-China relations: new directions, new priorities. Friends of Europe, Brussels, pp 135-137

Long J (2014) Relations between China and CEE countries: development, challenges and recommendations. China. Int Stud 5:44-60

Mattlin M (2012) Dead on arrival: normative EU policy toward China. Asia Eur J 10(2):181-198

Meunier S (2014) Divide and conquer? China and the cacophony of foreign investment rules in the EU. J Eur Public Policy 21(7):996-1016. https://doi.org/10.1080/13501763.2014.912145

Petrakis M, Chang L (2016) Passage to Piraeus. China Daily, 15 April Retrieeved 20 February, from http://europe.chinadaily.com.cn/epaper/2016-04/15/content_24560625.htm

Pieke F (2016) Knowing China: a twenty-first century guide. Cambridge University Press, Cambridge. https://doi.org/10.1017/CBO9781316452097

van der Putten FP (ed) (2016) The geopolitical relevance of Piraeus and China's New Silk Road for Southeast Europe and Turkey. Netherlands Institute of International Relations Clingendael, The Hague

Shambaugh D, Sandschneider E, Zhou H (eds) (2008) China-Europe relations: perceptions, policies and prospects. Routledge, London and New York

Shi ZQ (2012) Understanding China-EU relations. Website Carnegie-Tsinghua Center for Global Policy, 15 October. Retrieved 27 February 2017, from http:/carnegietsinghua.org/2012/10/15/understanding-chinaeu-relations-pub-49688 
Song XN (2011) The European Union as an international political and security actor. In: European Commission, DG Education and Culture (ed) The European Union after the Treaty of Lisbon: visions of leading policy-makers, academics and journalists. EU Publications Office, Luxemburg, pp 237-241

Szczudlik J (2016) China-EU relations: post-summit perspectives. Bulletin Polish Institute of Int Affairs, 45(895), 27 July. Retrieved 11 January 2017, from http://www.pism.pl/files/?id_plik=22145

Tiessalo R, Shi T (2017) Xi's Nordic stopover on his way to US reveals a global trade shift. Bloomberg, 3 April. Retrieved 4 April 2017, from https://www.bloomberg.com/politics/articles/2017-04-03/xi-s-nordicstopover-on-way-to-trump-reveals-global-trade-shift

Wang YW (2009) The identity dilemmas of EU normative power: observations from Chinese traditional culture. In: Gerrits A (ed) Normative power Europe in a changing world: a discussion. Netherlands Institute of International Relations Clingendael, The Hague, pp 67-76

Wang ZX (2015) Europe in China's incremental intercontinentalism. Asian Pol Policy 7(1):131-144. https://doi.org/10.1111/aspp.12165

Wang YW (2016) The belt and road initiative: what China will offer the world in its rise. New World Press, Beijing

Wu W (2017) EU to seek reciprocity from China at top-level talks this week. South China Morning Post, 31 May. Retrieved 5 June 2017, from http://www.scmp.com/news/china/diplomacy-defence/article/2096069 /eu-seek-reciprocity-china-top-level-talks-week

Xi JP (2014) Keynote speech at the College of Europe, 1 April. Retrieved 17 February 2017, from http://www. china.org.cn/world/2014-04/04/content_32004856.htm

Xi JP (2017a) Keynote speech at world economic forum, 17 January. Retrieved 17 February 2017, from http://www.china.org.cn/node_7247529/content 40569136.htm

Xi JP (2017b) Our enduring friendship. Helsinki Times, 3 April. Retrieved 4 April 2017, from http:/www. helsinkitimes.fi/149-finland/14658-our-enduring-friendship.html

Xi JP (2017c) Securing a decisive victory in building a moderately prosperous society in all respects and striving for the great success of Socialism with Chinese Characteristics in the New Era (Full text of Xi Jinping's report at 19th CPC National Congress). Xinhua, 4 November. Retrieved 21 December 2017, from http://www.chinadaily.com.cn/china/19thcpcnationalcongress/2017-11/04/content 34115212.htm

Xinhua (2016) AIIB has swift start, solid governance, good cooperation: Dutch policy advisor Xinhua, 14 September. Retrieved 20 February 2017, from http://news.xinhuanet.com/english/2016-09/14 /c 135685630.htm

Xinhua (2017) Spotlight: with Premier Li in Europe, China set to deepen, enrich ties with EU Xinhua, 28 May. Retrieved 5 June 2017, from http://news.xinhuanet.com/english/2017-05/28/c_136322698.htm

Yan XT (interview by Vandaele J) (2016) We gaan onvermijdelijk naar een bipolaire wereld. MO Mondiaal Mag 119:30-33

Zeng JH (2017) Does Europe matter? The role of Europe in Chinese narratives of 'One Belt One Road' and 'New Type of Power Relations. J Common Mark Stud. https://doi.org/10.1111/jcms.12535

Zhang L (2016) 'Reflexive expectations' in EU-China relations: a media analysis approach. J Common Mark Stud 54(2):463-479. https://doi.org/10.1111/jcms.12286

Zhang L, Yu Y (2013) Chinese views of the EU: overview of survey findings. In: Dong LS, Wang ZX, Dekker $\mathrm{H}$ (eds) China and the European Union. Routledge, London and New York, pp 11-36

Zhang HZ, Zhang CY (2011) Europe can overcome crisis, China says China Daily, 9 September. Retrieved 5 June 2017, from http://www.pressreader.com/china/china-daily-usa/20110909/281492158034997

Zhou H (ed) (2013) Zhong-Ou guanxi yanjiu baogao, 2014: Pandian zhanlüe huoban guanxi shi nian. Social Sciences Academic Press, Beijing

Zhu LQ (2008) Chinese perceptions of the EU and the China-Europe relationship. In: Shambaugh D, Sandschneider E, Zhou H (eds) China-Europe relations: perceptions, policies and prospects. Routledge, London and New York, pp 148-173 